\title{
The Sport Concussion Education Project. A brief report on an educational initiative: from concept to curriculum
}

\section{Citation}

Echlin, Paul S., Andrew M. Johnson, Jeffrey D. Holmes, Annalise Tichenoff, Sarah Gray, Heather Gatavackas, Joanne Walsh, et al. 2014. "The Sport Concussion Education Project. A Brief Report on an Educational Initiative: From Concept to Curriculum." Journal of Neurosurgery 121 (6) (December): 1331-1336. doi:10.3171/2014.8.jns132804.

\section{Published Version}

doi:10.3171/2014.8.JNS132804

\section{Permanent link}

http://nrs.harvard.edu/urn-3:HUL.InstRepos:35164972

\section{Terms of Use}

This article was downloaded from Harvard University's DASH repository, and is made available under the terms and conditions applicable to Open Access Policy Articles, as set forth at http:// nrs.harvard.edu/urn-3:HUL.InstRepos:dash.current.terms-of-use\#OAP

\section{Share Your Story}

The Harvard community has made this article openly available.

Please share how this access benefits you. Submit a story.

Accessibility 


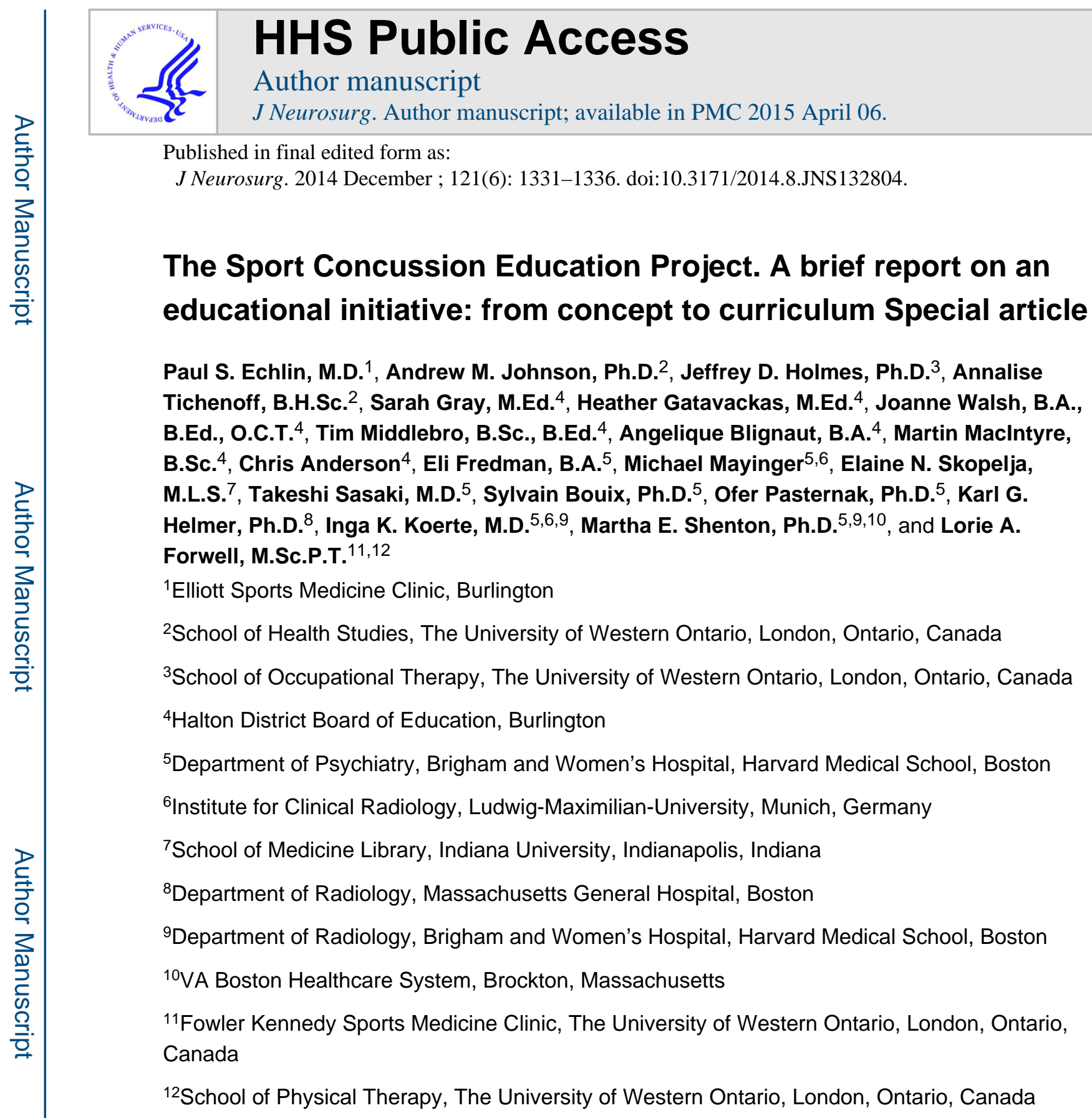

\section{Abstract}

()AANS, 2014

Address correspondence to: Paul Echlin, M.D., Elliott Sports Medicine Clinic, 1100 Walkers Line, Ste. 102, Burlington, ON L7N 2G3, Canada.psechlin@gmail.com.

Current affiliation for Dr. Koerte: Department of Child and Adolescent Psychiatry, Psychosomatic, and Psychotherapy, LudwigMaximilian-University, Munich, Germany.

Author contributions to the study and manuscript preparation include the following. Conception and design: Echlin, Johnson, Gray, Gatavackas, Walsh, Blignaut, MacIntyre, Anderson, Skopelja, Forwell. Acquisition of data: Echlin, Johnson, Holmes, Tichenoff, Gray, Gatavackas, Walsh, Middlebro, Blignaut, MacIntyre, Anderson, Forwell. Analysis and interpretation of data: Echlin, Johnson, Holmes, Tichenoff, Gray, Walsh, Forwell. Drafting the article: Johnson, Holmes, Tichenoff, Gatavackas, Walsh, Anderson, Skopelja, Shenton, Forwell. Critically revising the article: all authors. Reviewed submitted version of manuscript: all authors. Approved the final version of the manuscript on behalf of all authors: Echlin. Statistical analysis: Johnson, Holmes, Tichenoff. Administrative/ technical/material support: Echlin, Johnson, Holmes, Gatavackas, Walsh, Middlebro, Blignaut, MacIntyre, Anderson, Fredman, Mayinger, Skopelja, Sasaki, Bouix, Pasternak, Helmer, Koerte, Shenton, Forwell. Study supervision: Echlin, Johnson, Holmes, Gray, Gatavackas, Walsh, Middlebro, Blignaut, MacIntyre, Forwell. IT support: Anderson. Librarian support: Skopelja. 
Current research on concussion is primarily focused on injury identification and treatment. Prevention initiatives are, however, important for reducing the incidence of brain injury. This report examines the development and implementation of an interactive electronic teaching program (an e-module) that is designed specifically for concussion education within an adolescent population. This learning tool and the accompanying consolidation rubric demonstrate that significant engagement occurs in addition to the knowledge gained among participants when it is used in a school curriculum setting.

\section{Keywords}

concussion; mild traumatic brain injury; education; student; youth athlete

Athletic and recreational concussions are a significant health concern among young people, owing to the developmental vulnerability of this population. The Centers for Disease Control and Prevention (CDC) estimate that approximately 1.7 million traumatic brain injuries (TBIs) occur per year, of which the majority are classified as minor TBI (mTBI) or concussion, and that these injuries occur predominantly among children and adolescents. ${ }^{16}$ The number of secondary school athletes who are diagnosed with sport-related concussions is rising - current estimates suggest that more than half of young athletes will experience some type of concussive injury before graduating from secondary school. ${ }^{21,25}$ This increased prevalence is likely due to a combination of increased injury reporting and higher rates of injury that result from more highly conditioned, hard-hitting athletes participating in full-contact practices and games. ${ }^{2,21}$ Insufficient concussion identification and treatment and the significant long-term health and social implications of concussion have been well documented in the literature. ${ }^{8,9,22-24,26,28,30,31}$

Despite improved public awareness of this injury, identified in a CDC report to the US Congress in 2002 as an important health problem and referred to as "the silent epidemic,"32 prevention and treatment guidelines have met with considerable resistance among adults (e.g., parents, coaches, and administrators) who are responsible for providing young athletes with a safe and positive sporting environment. ${ }^{4,11,12}$ This resistance appears to result from 3 factors: 1) lack of correct standardized concussion knowledge; 2) inaccurate incidence reporting; $6,10-12,15,17,18,25,27$ and 3) prioritizing winning athletic contests over injury prevention. ${ }^{12,29,35}$

Children and adolescents do not reliably recognize their own concussion symptoms, or those of others. Similarly, children and youth are unlikely to report having sustained a potential head injury even with symptoms of headache, dizziness, or amnesia. ${ }^{19}$ Youth may also be hesitant to report concussive symptoms because they do not know what they may mean, or because of concern about how these reports will be received by their coach. ${ }^{4}$ Evidence, in fact, indicates that concussion education increases the likelihood that secondary school athletes will notify their coach of concussion symptoms. ${ }^{9}$

The foregoing illustrates that concussion education (on prevention, accurate recognition, and appropriate treatment) is an essential component of concussion management. Public education is a significant conduit for informing the next generation of athletes, coaches, and 
parents concerning this serious problem, and concussion education has had moderate success in increasing knowledge and awareness. ${ }^{33}$ The current literature suggests that there is some evidence supporting the use of interactive computer programs, such as e-modules, for concussion education purposes. ${ }^{5,13}$ In the present study, we further analyze the use of emodules as education tools for students.

\section{Project Development}

\section{E-Module}

An e-module is a series of student familiar scenarios, presented in an electronic form, that are both age and language appropriate. For this project, each scenario contains multiple learning concepts concerning concussion injury. Students are asked to both listen to and watch the scenario either individually or in a group environment and then to answer questions concerning the learning points stressed in that particular scenario. After a student has answered the question set, the correct answers are given, followed by a brief explanation and reinforcement of the concepts covered.

Our current e-module has evolved over several iterations within the Hockey Concussion Education Project (HCEP) ${ }^{11,14}$ and is freely accessible to the public and educational institutions at www.sportconcussionlibrary.com. The purpose of the e-module is to provide an interactive learning platform for improving concussion knowledge, based on the most recent information concerning concussion from the Consensus Statement on Concussion in Sport: The 4th International Conference on Concussion in Sport, held in Zurich, November 2012 (2012 Zurich Consensus Statement). ${ }^{28}$

\section{E-Module Versus DVD Study}

In 2010, a group of randomly selected junior-level hockey players were exposed to the first version of the interactive e-module and were compared with an equal number of individuals within the study group who were exposed to a DVD (a passive versus an interactive experience) containing similar information, and a control group of participants who were not exposed to either the e-module or the DVD.

Findings showed that both forms of intervention produced a positive and sustainable improvement that approached statistical significance compared with the results of knowledge testing in the control group. The control group demonstrated a longitudinal negative nonsignificant trend with respect to concussion knowledge retention. ${ }^{13}$ The complete methodology and results of this HCEP 2009-2010 education pilot project have been previously reported. ${ }^{13}$

\section{Secondary School Pilot of E-Module}

The most recent concussion project sampled Grade 9 students from a sampling frame of 4 Ontario secondary schools (358 students, 13-14 years old). The current version of the emodule was further developed, appropriately modified, and incorporated into the health and physical education course within these secondary schools. This resulted in a response rate for the study of $83.5 \%$. All participants completed a baseline concussion knowledge test, 
and a crossover design was then used to assess the knowledge gain resulting from exposure to the e-module. The amount of knowledge gained was significantly greater among participants who were exposed to the e-module before follow-up testing (95\% CI 4.44\%$7.56 \%$ ) than among participants who were exposed to the e-module after follow-up testing (95\% CI 0.39\%-3.43\%). The complete methodology, statistical analysis, and results are presented in the Appendix and Table 1.

Although the knowledge gains were small within this early validation study (possibly due to ceiling effects on the concussion knowledge test), this study suggested that e-modules are an engaging method of content presentation and may provide a foundation for discussion and knowledge consolidation within this topic. Future studies are required to investigate longterm retention of this knowledge as well as qualitative information that includes the impact on attitudes and objectively measured behaviors. The current elementary and secondary school versions of the e-module as well as the learning consolidation rubric will be accessible at www.sportconcussionlibrary.com after publication.

\section{Current E-Module Utilization}

After the initial pilot phase, the e-module and the curriculum learning consolidation rubric (Fig. 1) are to be revised in response to feedback from practice leaders within the school board, physical education teachers, and Grade 9 and elementary school students. During the 2014-2015 school year, the e-module and a learning consolidation rubric are being implemented across all schools within the Halton District School Board (Ontario, Canada) as part of the Grade 9 physical education programs. Furthermore, modified versions of the emodule have been developed to align with the language level and learning needs of elementary school children (Grade 3 and 6 curriculums, Ontario, Canada), and this version will be piloted in 5 Halton District School Board elementary school safety and personal health programs in the fall of 2014, for wider distribution in the 2014-2015 school year. This strategy reflects the fact that individuals at various stages of learning and with different levels of responsibility (e.g., students, athletes, physicians, coaches, and therapists) may require different strategies. $1,3,34$

\section{Discussion}

The introduction of concussion information during the critical developmental period spanned by elementary and secondary school correlates with the time that students are introduced to competitive sporting activities and are at significant risk of TBI. A longitudinal educational program that is developed collaboratively with educators is likely to be better received and to provide greater utility than those developed exclusively by external organizations without direct educator consultation.

The present study also found that the e-module education tool developed through this project demonstrated significant engagement during the data collection process, as well as leading to a short-term increase in knowledge acquisition. The development and implementation of a longitudinal consolidation component may improve long-term retention of the information. ${ }^{1}$ 
According to current theory, learning requires more than a single, passive provision of isolated knowledge units. Effective learning requires repetition, reassessment, identification of the current barriers, and identification of the most effective learning strategy for the targeted group. ${ }^{7,20,33,34}$ Thus, early and repeated education concerning concussion (at the elementary and secondary school levels) is one method to further consolidate future behaviors. These educational efforts will be enhanced by leveraging currently available internationally recognized concussion education organizations and their associated programs, as well as appropriate use of emerging on-line tools. ${ }^{34,36,37}$

Although this e-module-based modality of knowledge transfer seems to be effective for Grade 9 students, there is still no evidence as to which teaching modality is most appropriate for delivering concussion education. ${ }^{33}$ Individuals at various stages of learning and with different levels of responsibility (e.g., students, athletes, physicians, coaches, and therapists) may require different strategies. ${ }^{1,3,34}$ Furthermore, concussions are complex functional impairments that impact physical function, psychological and intellectual variables, and social environments. ${ }^{27}$ The provision of knowledge through an e-module-based education program may be only one of many approaches to the larger problem. ${ }^{1}$ Future research should focus on delving deeper into the complex and critical issues associated with concussions. ${ }^{31}$ This can be accomplished with the use of various psychological models of behavior change (e.g., Theory of Planned Behavior, Attitude Social Influence Self Efficacy Model, and Health Action Process Approach). ${ }^{38}$

Finally, common misconceptions about concussion and poor adherence to current clinically accepted treatment guidelines (e.g., the 2012 Zurich Consensus Statement) need to be targeted. ${ }^{26,28}$ Improving educational initiatives is one way of decreasing the incidence of this injury. Increased awareness will be important for early identification of injury, improved documentation of injury, and better monitoring during treatment.

\title{
Acknowledgments
}

We acknowledge the participating Halton District School Board, Ontario, Canada, and the participating students, staffs, and administrators of the involved schools. We would also like to acknowledge the participating research assistants and volunteers for their contributions.

This work is funded by the Ontario Trillium Foundation, the Dave Irwin Foundation for Brain Injury Recovery, the Ontario Neurotrauma Foundation, Air Canada, the Ontario Ministry of Health and Long-Term Care, the Ontario Ministry of Tourism, Culture and Sport, and the Ontario Ministry of Education. This work was partially funded by grants from the National Institutes of Health (NIH) (P41RR013218, P41EB015902, R01MH074794), the Department of Defense (X81XWH-07-CC-CSDoD), and a VA merit grant. Dr. Ofer Pasternak was partially supported by a NARSAD Young Investigator grant from the Brain \& Behavior Research Foundation. Dr. Inga Koerte is supported by the Else Kröner-Fresenius Stiftung, Germany. Dr. Takeshi Sasaki is supported by the Strategic Young Researcher Overseas Visits Program for Accelerating Brain Circulation from the Japan Society for the Promotion of Science. Mr. Michael Mayinger is supported by the Petraeic Legate Foundation. Dr. Shenton is a consultant on an NIH grant to SUNY on velocardiofascial syndrome and on a grant supported by the Henry Jackson Foundation.

\section{Abbreviations used in this paper}

\author{
CDC Centers for Disease Control and Prevention \\ HCEP Hockey Concussion Education Project
}


traumatic brain injury

\section{References}

1. Bonk C, Zhang K. Introducing the R2D2 Model: Online learning for the diverse learners of this world. Distance Educ. 2006; 27:249-264.

2. Bramley H, Patrick K, Lehman E, Silvis M. High school soccer players with concussion education are more likely to notify their coach of a suspected concussion. Clin Pediatr (Phila). 2012; 51:332336. [PubMed: 22007039]

3. Burke MJ, Chundamala J, Tator CH. Deficiencies in concussion education in Canadian medical schools. Can J Neurol Sci. 2012; 39:763-766. [PubMed: 23230614]

4. Chrisman SP, Quitiquit C, Rivara FP. Qualitative study of barriers to concussive symptom reporting in high school athletics. J Adolesc Health. 2013; 52:330-335.e3. [PubMed: 23427783]

5. Ciavarro C, Dobson M, Goodman D. Implicit learning as a design strategy for learning games: Alert Hockey. Comput Human Behav. 2008; 24:2862-2872.

6. Cusimano MD. Canadian minor hockey participants' knowledge about concussion. Can J Neurol Sci. 2009; 36:315-320. [PubMed: 19534331]

7. Cusimano MD, Chipman M, Donnelly P, Hutchison MG. Effectiveness of an educational video on concussion knowledge in minor league hockey players: a cluster randomised controlled trial. Br J Sports Med. 2014; 48:141-146. [PubMed: 23918445]

8. De Beaumont L, Lassonde M, Leclerc S, Théoret H. Long-term and cumulative effects of sports concussion on motor cortex inhibition. Neurosurgery. 2007; 61:329-337. [PubMed: 17762745]

9. De Beaumont L, Théoret H, Mongeon D, Messier J, Leclerc S, Tremblay S, et al. Brain function decline in healthy retired athletes who sustained their last sports concussion in early adulthood. Brain. 2009; 132:695-708. [PubMed: 19176544]

10. Delaney JS, Lacroix VJ, Leclerc S, Johnston KM. Concussions during the 1997 Canadian Football League season. Clin J Sport Med. 2000; 10:9-14. [PubMed: 10695844]

11. Echlin PS. Concussion education, identification, and treatment within a prospective study of physician-observed junior ice hockey concussions: social context of this scientific intervention. Neurosurg Focus. 2010; 29(5):E7. [PubMed: 21039141]

12. Echlin PS. Editorial. A prospective study of physician-observed concussion during a varsity university ice hockey season. Part 1 of 4. Neurosurg Focus. 2012; 33(6):E1. [PubMed: 23199421]

13. Echlin PS, Johnson AM, Riverin S, Tator CH, Cantu RC, Cusimano MD, et al. A prospective study of concussion education in 2 junior ice hockey teams: implications for sports concussion education. Neurosurg Focus. 2010; 29(5):E6. [PubMed: 21039140]

14. Echlin PS, Skopelja EN, Worsley R, Dadachanji SB, Lloyd-Smith DR, Taunton JA, et al. A prospective study of physician-observed concussion during a varsity university ice hockey season: incidence and neuropsychological changes. Part 2 of 4. Neurosurg Focus. 2012; 33(6):E2. [PubMed: 23199425]

15. Echlin PS, Tator CH, Cusimano MD, Cantu RC, Taunton JE, Upshur REG, et al. A prospective study of physician-observed concussions during junior ice hockey: implications for incidence rates. Neurosurg Focus. 2010; 29(5):E4. [Erratum in Neurosurg Focus 29(5):erratum, 2010]. [PubMed: 21039138]

16. Faul, M.; Xu, L.; Wald, MM.; Coronado, VG. Traumatic Brain Injury in the United States: Emergency Department Visits, Hospitalizations, and Deaths 2002-2006. Atlanta: Centers for Disease Control and Prevention, National Center for Injury Prevention and Control; 2010. (http:// www.cdc.gov/traumaticbraininjury/pdf/blue_book.pdf) [Accessed August 28, 2014]

17. Faure C. Creating concussion management policy: how school leaders, coaches and parents can work together to ensure kids stay safer in sport. Am Secondary Educ. 2010; 39:5-14.

18. Faure, CE.; Pemberton, CLA. [Accessed August 28, 2014] An examination of Idaho high school football coaches' general understanding of concussion. The Sport Journal. Jan 12. 2011 (http:// 
thesportjournal.org/article/an-examination-of-idaho-high-school-football-coaches-generalunderstanding-of-concussion/)

19. Gioia GA, Schneider JC, Vaughan CG, Isquith PK. Which symptom assessments and approaches are uniquely appropriate for paediatric concussion? Br J Sports Med. 2009; 43 (Suppl 1):i13-i22. [PubMed: 19433419]

20. Graham ID, Logan J, Harrison MB, Straus SE, Tetroe J, Caswell W, et al. Lost in knowledge translation: time for a map? J Contin Educ Health Prof. 2006; 26:13-24. [PubMed: 16557505]

21. Guerriero RM, Proctor MR, Mannix R, Meehan WP III. Epidemiology, trends, assessment and management of sport-related concussion in United States high schools. Curr Opin Pediatr. 2012; 24:696-701. [PubMed: 23042252]

22. Guskiewicz KM, Marshall SW, Bailes J, McCrea M, Cantu RC, Randolph C, et al. Association between recurrent concussion and late-life cognitive impairment in retired professional football players. Neurosurgery. 2005; 57:719-726. [PubMed: 16239884]

23. Guskiewicz KM, Marshall SW, Bailes J, McCrea M, Harding HP Jr, Matthews A, et al. Recurrent concussion and risk of depression in retired professional football players. Med Sci Sports Exerc. 2007; 39:903-909. [PubMed: 17545878]

24. Kaut KP, DePompei R, Kerr J, Congeni J. Reports of head injury and symptom knowledge among college athletes: implications for assessment and educational intervention. Clin J Sport Med. 2003; 13:213-221. [PubMed: 12855923]

25. Langlois JA, Rutland-Brown W, Wald MM. The epidemiology and impact of traumatic brain injury: a brief overview. J Head Trauma Rehabil. 2006; 21:375-378. [PubMed: 16983222]

26. Lincoln AE, Caswell SV, Almquist JL, Dunn RE, Norris JB, Hinton RY. Trends in concussion incidence in high school sports: a prospective 11-year study. Am J Sports Med. 2011; 39:958-963. [PubMed: 21278427]

27. McCrea M, Hammeke T, Olsen G, Leo P, Guskiewicz K. Unreported concussion in high school football players: implications for prevention. Clin J Sport Med. 2004; 14:13-17. [PubMed: 14712161]

28. McCrory P, Meeuwisse WH, Aubry M, Cantu B, Dvorák J, Echemendia RJ, et al. Consensus statement on concussion in sport: the 4th International Conference on Concussion in Sport held in Zurich, November 2012. Br J Sports Med. 2013; 47:250-258. [PubMed: 23479479]

29. McKee AC, Cantu RC, Nowinski CJ, Hedley-Whyte ET, Gavett BE, Budson AE, et al. Chronic traumatic encephalopathy in athletes: progressive tauopathy after repetitive head injury. $\mathrm{J}$ Neuropathol Exp Neurol. 2009; 68:709-735. [PubMed: 19535999]

30. McKinlay A, Bishop A, McLellan T. Public knowledge of 'concussion' and the different terminology used to communicate about mild traumatic brain injury (MTBI). Brain Inj. 2011; 25:761-766. [PubMed: 21619461]

31. Moser RS, Schatz P, Jordan BD. Prolonged effects of concussion in high school athletes. Neurosurgery. 2005; 57:300-306. [PubMed: 16094159]

32. National Center for Injury Prevention and Control. Report to Congress on Mild Traumatic Brain Injury in the United States: Steps to Prevent a Serious Public Health Problem. Atlanta: Centers for Disease Control and Prevention; 2003. (http://www.cdc.gov/ncipc/pub-res/mtbi/mtbireport.pdf) [Accessed August 28, 2014]

33. Provvidenza C, Engebretsen L, Tator C, Kissick J, McCrory P, Sills A, et al. From consensus to action: knowledge transfer, education and influencing policy on sports concussion. Br J Sports Med. 2013; 47:332-338. [PubMed: 23349319]

34. Provvidenza CF, Johnston KM. Knowledge transfer principles as applied to sport concussion education. Br J Sports Med. 2009; 43 (Suppl 1):i68-i75. [PubMed: 19433428]

35. Sarmiento K, Mitchko J, Klein C, Wong S. Evaluation of the Centers for Disease Control and Prevention's concussion initiative for high school coaches: "Heads Up: Concussion in High School Sports. J Sch Health. 2010; 80:112-118. [PubMed: 20236412]

36. Saunders EA, Burdette GT, Metzler JN, Joyner AB, Buckley TA. Knowledge of coaching education students regarding sport-related concussions. Athletic Training \& Sports Health Care. $2013 ; 5: 175-183$. 
37. Sawyer RJ, Hamdallah M, White D, Pruzan M, Mitchko J, Huitric M. High school coaches' assessments, intentions to use, and use of a concussion prevention toolkit: Centers for Disease Control and Prevention's heads up: concussion in high school sports. Health Promot Pract. 2010; 11:34-43. [PubMed: 18400880]

38. Schwarzer R, Lippke S, Luszczynska A. Mechanisms of health behavior change in persons with chronic illness or disability: the Health Action Process Approach (HAPA). Rehabil Psychol. 2011; 56:161-170. [PubMed: 21767036]

\section{Appendix: Methodology, Analysis, and Results of the 2012-2013 Sport Concussion Education Project}

\section{Methods}

\section{Patient Population}

The sampling frame consisted of Grade 9 physical education students (average age 13-14 years) at 4 public secondary schools. In order to be included in the study sample, students were required to participate in the 2 required testing sessions and provide written parental consent. Of the 358 students that were present on both testing days, 59 students did not provide parental consent, yielding a response rate of $83.5 \%$. Of these 299 participants, 153 were randomly assigned to the control group ( 79 boys, 74 girls) and 146 were randomly assigned to the experimental condition ( 80 boys, 66 girls).

The study protocol and consent documentation were approved by the Health Sciences Research Ethics Board at the University of Western Ontario as well as the Research Advisory Committee of the Halton District School Board.

\section{Procedure}

Data were collected in the winter term of the 2012-2013 school year, within a mandatory health and physical education course. For each class included in the sample, 2 research sessions were held, with a 1-week period between them. Each session was conducted under the supervision of study personnel and teacher(s).

During the first session, all students were asked to independently complete a 25-question multiple-choice and true/false test pertaining to basic concussion knowledge. The test was consistent with the 2012 Zurich Consensus Statement, ${ }^{28}$ and questions focused on the signs and symptoms of concussions, possible treatment options, suggested postconcussion practice, and return-to-play guidelines. This test served to establish the baseline level of concussion knowledge for all participants. There was no time limit for the completion of this test.

At the beginning of the second session (1 week after the first session), all participating students were randomly assigned to either the "experimental" group or the "control" group, and the groups were sent to separate classrooms. The experimental group was first presented with a 40-minute concussion education e-module, and the students then completed the same knowledge test as was administered during the first session. The control group was administered the knowledge test first and then proceeded to complete the e-module. In both 
groups, the activities were administered successively, without a break between the knowledge test and the e-module.

The concussion education e-module content was based on the 2012 Zurich Consensus Statement ${ }^{28}$ relating to concussion injury knowledge and clinical treatment protocols and was developmentally appropriate for Grade 9 secondary school students. It was originally developed and utilized by Echlin et al. in the study of physician-observed concussions during junior ice hockey, published in $2010 .{ }^{15}$ Although the e-module utilized in this study was designed for use on an individual student level (i.e., individual interaction with the emodule in a computer laboratory setting), it was logistically necessary to administer the module within a group setting for this study. To this end, the module was displayed through an overhead digital projector unit, with audio played through an accompanying speaker system. The format of information presented within the e-module was staged as generic multiple-choice questions that were to be answered by the student. Each question could be read by the student as well as listened to through recorded voice overlays to reinforce aural learning.

\section{Statistical Analysis}

The primary outcome measures within this study were the results of the knowledge test administered at each of the 2 time points. A basic knowledge level and an easily accessible literacy level were utilized to avoid frustrating participants. The inclusion of these lowvariability items in the final knowledge score would, however, significantly constrain knowledge variability within the sample and obscure the effects of the intervention. Accordingly, before completing an analysis of the results, the difficulty level of each item within the sample was assessed by determining the percentage of correct responses during the first session. Items were excluded from further analysis if more than $85 \%$ of participants correctly answered the question. The remaining items were averaged to create a unitweighted composite knowledge score.

A 2-factor split-plot analysis of variance was then used to evaluate this dependent variable, with condition (experimental vs control) and time (pretest vs posttest) as independent variables. The interaction between condition and time was of primary concern within this study, and the effectiveness of the educational intervention was examined through the use of simple main effects designed to evaluate the change from pretest to posttest within the experimental and control groups.

\section{Results}

Evaluation of the item difficulty scores for the 25 items on the knowledge test revealed that 13 of the 25 items had difficulty ratings that were less than 0.85 during the first testing session. These 13 items were aggregated in a unit-weighted composite at each time period. Means and standard deviations for scores on the knowledge test are presented in Table 1.

The 2-way interaction of time and condition was statistically significant $(F[1,297]=13.635$, $\mathrm{p}<0.05$ ). Examination of the simple main effects suggests that the pretest to posttest change was statistically significant for both the treatment and the control groups. This change was, 
however, significantly greater among participants within the treatment group $(95 \% \mathrm{CI}$ for the difference: $4.44 \%-7.56 \%$ ) compared with the control group (95\% CI for the difference: $0.39 \%-3.43 \%$ ). This suggests that the treatment group demonstrated a significantly greater increase in "concussion knowledge" between the 2 testing sessions than did the control group—and this suggests that the educational intervention was successful. 
Concussion Study - Curriculum Connections and Assessment

\begin{tabular}{|c|c|c|c|c|}
\hline \multicolumn{3}{|l|}{ Physical Activity Strand } & \multicolumn{2}{|c|}{ Big Ideas and Achievement Chart Categories. } \\
\hline $\begin{array}{l}\text { Overall Expectation: } \\
\text { - demonstrate knowledge } \\
\text { of guidelines and } \\
\text { strategies that enhance } \\
\text { participation in } \\
\text { recreational and sport } \\
\text { activities }\end{array}$ & \multicolumn{2}{|c|}{$\begin{array}{l}\text { Specific Expectation: } \\
\text { identify the factors that affect } \\
\text { choices of activities with } \\
\text { potential for lifelong } \\
\text { participation and enjoyment. }\end{array}$} & \multirow{3}{*}{\multicolumn{2}{|c|}{$\begin{array}{l}\text { Knowledge } \\
\text { - Pigns/Symptoms: basic physical, cognitive, emotional } \\
\text { Prevention } \\
\text { - Equipment: Helmet/ mouthguard } \\
\text { - } \quad \text { \& safe practices } \\
\text { Understanding } \\
\text { - When you know you have a concussion } \\
\text { - Implications of signs \& symptoms } \\
\text { - Short term restrictions and implications e.g., complete rest ( no videos / no texting etc.), } \\
\text { effecton grades, social activities, social } \\
\text { relationships etc. } \\
\text { - Long term effects - untreated/ multiple concussions on brain and learning } \\
\text { Thinking } \\
\text { - Other mechanisms to sustain concussion in P.A.: e.g. Skateboarding, PE class, slips and falls in a } \\
\text { pool, arena, at home etc. } \\
\text { - Critical Thinking: e.g. Why honesty caring of symptoms? What to do as a peer athlete/ } \\
\text { Friend who is masking symptoms? } \\
\text { - Decision making: e.g. Where and how to seek medical attention } \\
\text { conflict Resolution: Dealing with concussions/ depression/ limitations on P. A and learning/ } \\
\text { Application: } \\
\text { - What does this mean for me, my friends, my family, my decisions and actions? }\end{array}$}} \\
\hline \multicolumn{3}{|l|}{ Active Living Strand } & & \\
\hline $\begin{array}{l}\text { Overall Expectations: } \\
\text { - participate regularly } \\
\text { in a balanced } \\
\text { instructional program } \\
\text { that includes a wide } \\
\text { variety of enjoyable } \\
\text { physical activities that } \\
\text { encourage life long } \\
\text { participation } \\
\text { demonstrate safe } \\
\text { practices regarding the } \\
\text { safety of themselves } \\
\text { and others }\end{array}$ & \multicolumn{2}{|c|}{$\begin{array}{l}\text { Specific Expectations: } \\
\text { identify requirements, } \\
\text { including basic equipment, } \\
\text { preparation and specific safety } \\
\text { issues that maximize } \\
\text { performance and participation } \\
\text { in recreation and sport } \\
\text { activities }\end{array}$} & & \\
\hline \multicolumn{5}{|c|}{ Consolidation of Learning Strategies } \\
\hline \multicolumn{5}{|c|}{$\begin{array}{l}\text { Strategies to consolidate learning before beginning the assessment task: } \\
\text { - Explore stories of incidents of concussion and results e.g. Clara Hughes, Natasha Richardson, Ashley Stephenson and doorknobs, other known figures - athletes and } \\
\text { celebrities } \\
\text { View other videos on the Concussion Library website } \\
\text { - View segments of the movie, "Head Games" } \\
\text { Make models of the brain to demonstrate effects of concussion using Jello ( demonstrate consistency of brain and how it moves), Pipe cleaners ( to show how } \\
\text { synaptic connections are effected and interferes with messages and why it takes so long to repair/ recover from concussion) }\end{array}$} \\
\hline \multicolumn{5}{|c|}{ Assessment Methods: Write, Say, Do } \\
\hline \multicolumn{5}{|c|}{ Sample Assessment Tasks that are differentiated and may be used to provide students with the opportunity to demonstrate their learning: } \\
\hline \multicolumn{2}{|c|}{$\begin{array}{l}\text { Write: } \\
\text { - News article about concussion study- Why it } \\
\text { is taking place, what you have learned etc. } \\
\text { - Connect to one of Literacy test formats e.g. } \\
\text { opinion } \\
\text { - Create an Ad campaign for students } \\
\text { - Create an educational flyer for parents } \\
\text { - Exit pass }\end{array}$} & \multicolumn{2}{|c|}{$\begin{array}{l}\text { Say: } \\
\text { - Student conference } \\
\text { - Problem solve current issues e.g., } \\
\text { commissioner of sport/PA } \\
\text { - Hockey } \\
\text { - Floor ball } \\
\text { - Boarding } \\
\text { - Soccer }\end{array}$} & $\begin{array}{l}\text { Do } \\
\text { - info graphics } \\
\text { - ppt slide presentation } \\
\text { - create a brain model - before concussion/ } \\
\text { after concussion } \\
\text { - skit scenario ( use ipad to film and show) }\end{array}$ \\
\hline \multicolumn{5}{|c|}{ Connections to the Proclamation: What I have learned, What I believe, How I act on my beliefs. } \\
\hline \multicolumn{5}{|c|}{ (2) Positive Values - caring; honesty; responsibility; integrity; } \\
\hline
\end{tabular}

Fig. 1.

Curriculum learning consolidation rubric. Copyright 2013 Paul S. Echlin. Used with

permission. Available for the free use of educational institutions at http://

www.sportconcussionlibrary.com/content/hscep-halton-student-concussioneducationprogram via the link labeled "Curriculum Connections and Assessment." PA = physical activity. 
TABLE 1

Concussion knowledge test scores for each testing session

\begin{tabular}{lcc}
\hline Session \& Condition & No. of Participants & Percentage of Correct Answers (mean \pm SD) \\
\hline Session 1 & & \\
control & 153 & $82.30 \% \pm 12.75 \%$ \\
experimental & 146 & $82.55 \% \pm 11.44 \%$ \\
Session 2 & & \\
control & 153 & $84.21 \% \pm 12.76 \%$ \\
experimental & 146 & $88.55 \% \pm 10.19 \%$ \\
\hline
\end{tabular}

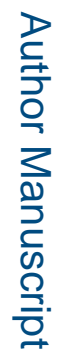

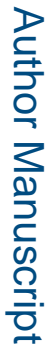

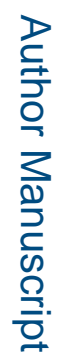

